\title{
Report of the Special Committee on Organ Transplantation
}

\begin{abstract}
A meeting of the Special Committee* on Organ Transplantation, set up by the Joint Consultants Committee "to consider the remaining transplantation problems on a wide basis, and possible amendments of the law in relation thereto," was held under the chairmanship of Sir John Richardson on 27 October 1969, when all members $\dagger$ except Mr. Myles Gibson were present. It considered the following issues left unsettled by the MacLennan Advisory Group. The present report is confined to these issues:
\end{abstract}

"Contracting out" or "contracting in" (should surgeons be able to remove organs unless there are definite indications that the deceased has objected?); a legal definition of the moment of death; the definition of the "person lawfully in possession" of the body of a patient who has just died in hospital.

\section{Contracting Out or Contracting In}

The MacLennan Advisory Group posed four possible options: no change in the existing law; limited amendment of the Human Tissue Act, 1961, to remove its ambiguities; double contract-that is, the establishment of a single public and central register for both consents and objections recorded during life; contracting out-that is, a change in the law to enable surgeons to remove organs, unless there are definite indications that the deceased has objected. Subject to safeguards (which present no small problem) the majority of the MacLennan Advisory Group favoured contracting out, but the Group was divided on this isssue.

\section{Contracting Out}

By contracting out, the Special Committee means the identification of those persons who have expressed unwillingness for their organs to be used after death in transplant procedures, accompanied by a change in the law to enable surgeons to remove organs from all persons not so identified. The MacLennan Advisory Group indicated that certain other countries have legislation in

*'The Special Committee was set up as a result of the Joint Consultants Committee meeting on 25 July 1969, at which the conclusions of the Advisory Groupl were accepted as far as they went,
but it was noted that certain issues were left unresolved.

†Members of the Special Committee were: Sir John Richardson, chairman of the Joint Consultants Committee (ex officio); Professor Sir Max Rosenheim, P.R.C.P.; Sir Thomas Holmes Sellors, P.R.C.S.; Professor T. N. A. Jeffcoate, P.R.C.O.G.; Mr. R. B. Wright, P.R.C.P. \& S.Glas.; Dr. J. G. M. Hamilton, vice-president R.C.P.Ed.; Mr. Bernard Nolan (nominated by R.C.S.Ed.); Professor C. Keith Simpson (nominated by R.C.Path.); Dr. Morris Markowe (nominated by the Royal Medico-Psychological Association); Dr. W. D. Wylie, Dean, Faculty of Association); Dr. W. D. Wylie, Dean, Faculty of of Radiologists; and Mr. R. Myles Gibson, of Radiologists; and Mr. R. Myles Gibson, (nominated by Chairman of the Ce
mittee for Hospital Medical Services). this sense, and expressed the opinion that implementation would depend on public acceptance and on there being a register of information to which transplant teams could have speedy access.

The unanimous opinion of the members of the Special Committee is that in the present climate of public opinion any attempt to legislate on the basis of contracting out would be premature, and, if pressed, might well jeopardize the future of transplant surgery. Organ transplantation is by no means universally accepted by the public. The circumstances in which a transplant operation is most likely to take place-sudden or accidental death of a young and otherwise healthy person, and the need for an immediate decision if use is to be made of any of his organs-are such as to give rise to a strong emotional reaction. Any attempt by a surgeon to carry out a transplant operation in the face of opposition by bereaved relatives, even with the law on his side, would be likely to provoke a hostile public reaction.

\section{Contracting In}

By contracting in, the Special Committee means the identification of those persons who have expressed willingness for their organs to be used after death in transplant procedures. Such identification could be either by means of a national or regional register or by the carrying of a suitable card or disc-possibly by a combination of both methods. One suggestion for the setting up of a register was to utilize the electoral registration machinery. Every householder is required by law to complete from time to time a form covering all persons normally resident in the house upon a given date. From these returns, the electoral register for the district is compiled and maintained. It would theoretically be possible for a question to be included in the form in reply to which the names of those willing to contract in would be recorded and for the details to be stored by computer, retrievable at will. This would not present any insuperable technical difficulties. The Special Committee doubts, however, whether public opinion is as yet sufficiently adjusted to transplant procedures to accept the inclusion of an inquiry of this kind in the electoral registration form.

A system of disc- or card-carrying, similar to the Medic-Alert token or the card carried by registered blood donors, appears to the Special Committee to be a more promising line of approach. It would be an entirely voluntary system of enrolment and would, if the token or card were habitually carried, permit immediate identification of willing donors. This could be combined with a voluntary register of those willing to donate organs, which could be built up on a regional basis, in the same way as volunteer blood donors are registered.

To be effective on any large scale, voluntary enrolment needs to be linked to careful and patient education of public opinion. One suggestion which commends itself to the Special Committee is that where a patient attends an accident and cmergency department and details of his blood group are recorded for precautionary purposes, he should be invited to co-operate in tissue typing, it being explained to the patient that if he is willing for his organs to be made available for transplantation after his death, essential information would thus be immediately available. This would also have the educational value of accustoming the public-particularly the younger and healthier members whose only contact with the hospital this may be-to the idea of organ donation as a rational and responsible reaction to a growing need.

\section{Double Contract}

By double contract, the Special Committee means the identification, in a single register, of persons who have expressed willingness and of persons who have expressed unwillingness for their organs to be used after death in transplant procedures. The considerations which apply to contracting in and contracting out apply equally to any form of double contract.

\section{Legal Definition of Death}

The Human Tissue Act, 1961, does not provide any statutory definition of death nor does it lay down criteria for determining the moment of death. The only reference is that contained in Section 1 (2) (4) that "No such removal [of any part of a body] shall be effected except by a fully registered medical practitioner who must have satisfied himself by personal examination that life is extinct."2 Various attempts have been made to establish criteria of death and the Special Committee noted those drawn up by the Harvard Medical School as characteristic of irreversible coma and acceptable as evidence of brain death. ${ }^{3}$

The Special Committee considered whether these or similar criteria should be written into the Human Tissue Act, 1961, but decided against recommending such a course. The view taken by the Special Committee is that there is no distinct group of clinical signs which, on each and every occasion, signify that death has occurred without possibility of error. The unanimous opinion of the Special Committee is therefore that the determination of death must, as now, be a matter of the individual doctor's judgement, and that the procedure laid down in paragraph 5(a) of the MacLennan Report

2 Human Tissue Act, 1961. Ch. 54.

3 Report of the Ad Hoc Committee of Harvard Medical School to Examine the Definition of Brain Death, fournal of the American of Brain Death, Fournal of the Amer
Medical Association, 1968, 205, 337. 
is as nearly proof against error as it is humanly possible to get. ${ }^{1}$ The Special Committee particularly emphasizes the need for careful record taking, as proposed in paragraph 5(a) of the MacLennan Report, because, apart from any subsequent value of the record itself, this will ensure that a careful and detailed examination of the donor for evidence of death is carried out in each case. The Special Committee concurs with the statement issued by the World Medical Association in 1968, which reads:

"This determination [of the point of death] will be based on clinical judgment supplemented if necessary by a number of diagnostic aids (of which the electroencephalograph is currently the most helpful). However, no single technical criterion is entirely satisfactory in the present state of medicine nor can any one technological procedure be substituted for the overall judgment of the physician."

The Special Committee is aware that peculiar problems arise when a potential donor is being maintained artificially alive on a respirator which in due time is switched off. A further complication is that it may then be switched on again after death as the most satisfactory method of perfusing the organ to be transplanted. In the Special Committee's view, both these problems are primarily matters of technique and do not invalidate the general proposition that the moment of death can be established only by the exercise of individual and personal clinical judgement by the doctors concerned.

The Special Committee supports the view of the MacLennan Advisory Group that a prospective donor should never be moved between hospitals merely in the interests of a prospective recipient. If there is a need for

1 Advice from the Advisory Group on Transplantation Problems on the Question of amending the Human Tissue Act, 1961,
Cmnd. 4106, H.M.S.O., London. 1969. transfer, the recipient should be moved to the donor.

\section{Definition of "Person Lawfully in Possession" of the Body}

The Human Tissue Act does not define "the person lawfully in possession of the body of a deceased person." In the case of a death occurring in hospital, the Departments of Health have advised ${ }^{4}$ that, until relatives claim the body, the person lawfully in possession of the body is the hospital management committee or board of governors or anyone designated so to act on their behalf. (In Scotland, it is the board of management.) The Department of Health and Social Security has further indicated that it considers that the consultant who has been in charge of the patient up to the time of death is a suitable person to be so designated. The Royal College of Pathologists dissents from this view and considers that the consultant should never be the person "lawfully in possession of the body" and the hospital authority only if no relative can be traced.

The Human Tissue Act also lays down that no authority may be given or acted upon when the person concerned has reason to believe that an inquest may be required to be held, or a post-mortem examination made, except with the consent of the coroner (in Scotland, the procurator-fiscal). Legally, a coroner can take charge of a body only when he has been officially informed of the death, and this rules him out in some cases and may be a cause of delay in others. Nevertheless, if ways can be found to bridge the gap in time-and there is evidence to suggest that coroners are not unco-operative in this matter-it seems to the Special Committee that the most satisfactory procedure would be

${ }^{4}$ H.M. (61)98 in England and Wales; S.H.M. (61) 72 in Scotland. for lawtul possession to be vested in the coroner (or procurator-fiscal) at time of death in any case where the law requires the death to be reported to the coroner (or procurator-fiscal), or in any other case where none of the relatives named below can readily be found. He would then be informed immediately of the death of a potential donor, and his permission to transplantation of organs secured. Where there is any question of criminal proceedings, the coroner (or procurator-fiscal) will obviously entertain no question of the transplantation of organs. In the Special Committee's view, the consultant who was in attendance upon the deceased patient is not in a position to determine whether a transplant is barred on these grounds.

The Human Tissue Act does not define the relatives who should be consulted more closely than "the surviving spouse or any surviving relative." The Royal College of Pathologists has suggested that it might be restricted to the following: spouse, adult son or daughter, either parent, adult brother or sister, executor or legal guardian of the deceased person.

The Special Committee considers that there is a case for amending the Human Tissue Act, 1961, in this sense and to this extent is in sympathy with paragraph 6(ii) of the MacLennan Report. ${ }^{1}$ The case will be much stronger if some system of identification of willing donors by card-carrying or voluntary registration takes root. The question arises whether transplantation should proceed where the donor is known to have been willing but the near relations, as defined, object. The Special Committee questions whether the wishes of a close relative should ever be overridden, even in the face of proof of willingness on the part of the donor but recognizes that such proof might be valuable in influencing the views of a relative.

The third supplement to the January 1969 consolidated list of Approved Names is printed below. Communications relating to Approved Names should be addressed to the Secretary, British Pharmacopoeia Commission, 8 Bulstrode Street, London, W1M 5FT.

\begin{tabular}{|c|c|c|c|c|c|c|c|}
\hline \multicolumn{2}{|c|}{ Approved Name } & \multirow{2}{*}{$\begin{array}{l}\text { Other Name } \\
\text { 3-(1-Hydroxy-2-methylaminoethyl)- } \\
\text { methanesulphonanilide } \\
\text { MJ } 5190 \text { is the mesylate }\end{array}$} & \multirow{2}{*}{$\begin{array}{l}\text { Action and Use } \\
\begin{array}{l}\text { Vasoconstrictor; } \\
\text { nasal decongestant }\end{array}\end{array}$} & \multicolumn{2}{|c|}{ Approved Name } & \multirow{2}{*}{ 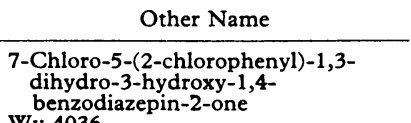 } & Action and Use \\
\hline Amidephrine & .. & & & Lorazepam & & & Tranquillizer \\
\hline $\begin{array}{l}\text { Betahistine } \\
\text { Clotrimazole }\end{array}$ & $\begin{array}{l}\cdots \\
.\end{array}$ & $\begin{array}{l}\text { 2-(2-Methylaminoethyl)pyridine } \\
\text { Serc is the dihydrochloride } \\
\text { 1-( } \alpha-2-\text {-Chlorophenylbenzhydryl) }\end{array}$ & $\begin{array}{l}\text { Diamine oxidase } \\
\text { inhibitor } \\
\text { Antimycotic agent }\end{array}$ & Loxapine & & $\begin{array}{l}\text { Wy } 4036 \\
2 \text {-Chloro-11-(4-methylpiperazin-1- } \\
\text { yl)dibenz- }[b, f][1,4 \text { ]oxazepine }\end{array}$ & Tranquillizer \\
\hline Clozapine & .. & $\begin{array}{l}\text { imidazole } \\
\text { FB b } 5097 \\
\text { 8-Chloro-11-(4-methylpiperazin-1-yl)- } \\
5 H \text {-dibenzo }[b, e][1,4] \text { diazepine }\end{array}$ & Sedative & Mepiprazole & & $\begin{array}{l}\text { 1-(3-Chlorophenyl)-4-[2-(5- } \\
\text { methylpyrazol-3-yl)ethyl]piperazine } \\
\text { H } 4007 \text { is the dihydrochloride }\end{array}$ & Psychotropic agent \\
\hline Dimepregnen & .. & $\begin{array}{l}\text { HF } 1854 \\
3 \beta-H y d r o x y-6 \alpha, 16 \alpha \text {-dimethylpregn- } \\
4-\text {-en-20-one } \\
\text { St } 1411\end{array}$ & Anti-oestrogen & $\begin{array}{l}\text { Octacosactrin } \\
\text { Panidazole }\end{array}$ & . & $\begin{array}{l}\text { 2-28h Corticotrophin } \\
\text { 2-Methyl-5-nitro-1-[2-(4- } \\
\text { pyridyl)ethyl]-imidazole }\end{array}$ & $\begin{array}{l}\text { Synthetic } \\
\text { corticotrophin } \\
\text { Amoebicide }\end{array}$ \\
\hline Dropropizine & . & $\begin{array}{l}\text { 1-(2,3-Dihydroxypropyl)-4- } \\
\text { phenylpiperazine Katril, } \\
\text { Catabex, Tussilex }\end{array}$ & Antitussive & Pendecamaine & .. & $\begin{array}{l}N N \text {-Dimethyl-(3- } \\
\text { palmitamidopropyl)aminoacetic } \\
\text { acid betaine }\end{array}$ & Surface active agent \\
\hline Enpiprazole & .. & $\begin{array}{l}\text { 1-(2-Chlorophenyl)-4-[2-(1- } \\
\text { methylpyrazol-4-yl)ethyl] } \\
\text { piperaine }\end{array}$ & Psychotropic drug & Perlapine & - & $\begin{array}{l}\text { Present in Tego-Betaines } \\
\text { 6-(4-Methylpiperazin-1-yl)-11H- } \\
\text { dibenz }[b, e]-\text {-azepine }\end{array}$ & Hypnotic \\
\hline Fluprednidene & . & $\begin{array}{l}\text { H } 3608 \text { is the dihydrochloride } \\
9 \alpha-\text { Fluoro-11 } 17,17,21 \text {-trihydroxy-16- } \\
\text { methylenepregna-1,4-diene-3,20- } \\
\text { dione }\end{array}$ & Glucocorticosteroid & Pivampicillin & . & $\begin{array}{l}\mathrm{HF}-2333, \mathrm{AW}-142333 \\
6-[\mathrm{D}(-)-\alpha-\text { Aminophenylacetamido]- } \\
\text { pencillinate } \\
\text { Pondocillin is the hydrochloride }\end{array}$ & Antibiotic \\
\hline Formocortal & . & $\begin{array}{l}\text { StC } 1106 \text { is the } 21 \text {-acetate } \\
21-\text { Acetoxy-3-(2-chloroethoxy)- } 9 \alpha- \\
\text { fluoro-6-formyl-11ß-hydroxy- }\end{array}$ & $\begin{array}{l}\text { Topical } \\
\text { corticosteroid }\end{array}$ & Pramiverine & . & $\begin{array}{l}\text { 4,4-Diphenyl- } N \text { - } \\
\text { isopropylcyclohexylamine } \\
\text { HSp } 2986\end{array}$ & Spasmolytic \\
\hline Isoprednidene & . & 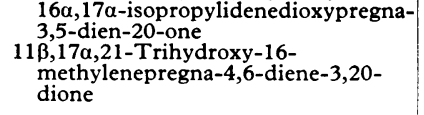 & A.C.T.H. inhibitor & Temazepam & . & $\begin{array}{l}\text { 7-Chloro-3-hydroxy-1-methyl-5- } \\
\text { phenyl-1H-1-4-benzodiazepin- } \\
2(3 H) \text {-one } \\
\text { 9- } \beta \text {-D-Arabinofuranosyladenine } \\
\text { CI } 673\end{array}$ & $\begin{array}{l}\text { Tranquillizer } \\
\text { Antiviral }\end{array}$ \\
\hline
\end{tabular}

.

